\title{
Chinese as a Foreign Language in Slovene Upper Secondary Education ANd OUtLINE of CURRICULUM Renewal
}

\author{
Mateja PETROVČıč \\ University of Ljubljana, Slovenia \\ mateja.petrovcic@ff.uni-lj.si
}

\begin{abstract}
This paper presents the position of Chinese in Slovene educational system. In most European countries, including Slovenia, the first foreign language is introduced in the lower grades of primary education, and the second foreign language as a compulsory subject is added a few years later, when students enter upper secondary education (ISCED 3). At the same time, the third foreign language may be added to the regular courses. Schools choose languages from a set list, and Chinese is one of the languages that can be taught at the ISCED 3 level. It is not available as second foreign language yet, but Chinese can be selected as a third foreign language. Recently, new initiatives have emerged to endorse Chinese as a second foreign language. The last part of the paper briefly highlights language curricula within the gimnazija programs and proposes the renewal of Chinese curriculum with four modules that provide horizontal and vertical continuity from ISCED 2 to ISCED 6.
\end{abstract}

Keywords: Chinese; third foreign language; second foreign language; curriculum renewal

\section{Povzetek}

Članek predstavi umestitev kitajskega jezika v slovenskem izobraževalnem sistemu. $V$ večini evropskih držav, vključno s Slovenijo, se učenci seznanijo s prvim tujim jezikom $v$ nižjih razredih osnovne šole, medtem ko postane drugi jezik obvezen nekaj let kasneje. V Sloveniji se obvezno učenje drugega jezika prične ob vpisu v gimnazijske programe. $V$ tem obdobju lahko dijaki in dijakinje izberejo tudi tretji tuji jezik, oboje iz nabora razpoložljivih jezikov, če ga, seveda, šola ponudi. Med njimi je tudi kitajščina. Trenutno jo je moč izbrati le kot tretji tuji jezik. Nedavno se je pojavila iniciativa po uvrstitvi kitajščine na seznam jezikov, ki so na voljo kot drugi tuji jezik. Zadnji del članka tako predstavi obstoječe učne načrte znotraj gimnazijskih programov in predlaga osnovanje štirih modulov, ki bi zagotavljali horizontalno in vertikalno povezavo od osnovnošolske do univerzitetne ravni.

Ključne besede: kitajščina; tretji tuji jezik; drugi tuji jezik; prenova učnega načrta

Acta Linguistica Asiatica, 8(1), 2018.

ISSN: 2232-3317, http://revije.ff.uni-lj.si/ala/

DOI: 10.4312/ala.8.1.27-37 


\section{Introduction}

In Slovenia, educational system is composed of three major clusters. According to the terminology used by Ministry of education, science and sport ${ }^{1}$, these clusters are called primarno izobraževanje (primary education), sekundarno izobraževanje (secondary education), and terciarno izobraževanje (tertiary education).

Primary education is further divided into predšolska vzgoja (pre-school education) and osnovnošolsko izobraževanje (basic education). In some publications of the Ministry of education, science and sport, the term "primary and lower secondary education" is used instead of the term "basic education".

Primary and lower secondary education ${ }^{2}$ is organised in a single-structure nineyear basic school attended by pupils aged 6 to 15 years (Taštanoska, 2015, p. 25).

In this context, the expression "primary education" does not denote the notion of primarno izobraževanje as stated above, but it refers to the so-called prva in druga triada (the first and the second cycle), i.e. grades 1-3 and 4-6. Similarly, the expression "lower secondary education" refers to the so-called tretja triada (the third cycle/triad), i.e. grades 7-9.

"Secondary education" is consequently called "upper secondary education" as a complementary term to the "lower secondary education".

The next stage after nine years of compulsory basic education is two- to five-year non-compulsory upper secondary education that begins at the age of 15 (Taštanoska, 2015, p. 29).

To avoid ambiguity of the above mentioned expressions, this paper uses terms that are in line with the International Standard Classification of Education (ISCED). This classification distinguishes between nine levels of education. Levels that are relevant for the discussion in this paper include:

- ISCED 1: Primary education. This level begins between 5 and 7 years of age, is compulsory in all countries and generally lasts from four to six years (Eurydice, 2017, p. 145). This corresponds to the prva in druga triada (the first and the second cycle) or to the first sixth grades in Slovenia.

- ISCED 2: Lower secondary education. This level typically begins around the age of 11 or 12 and usually ends at age 15 or 16 , often coinciding with the end of compulsory education (Eurydice, 2017, p. 145). This corresponds to the tretja triada (the third cycle) or to the last three grades in Slovenia.

\footnotetext{
${ }^{1}$ Ministry's webpage is available at http://www.mizs.gov.si/.

${ }^{2}$ Underline added by author in this and the following quotation.
} 
- ISCED 3: Upper secondary education. This level generally begins at the end of compulsory education. The entry age is typically age 15 or 16 . The duration of ISCED level 3 varies from two to five years. (Eurydice, 2017, p. 145).

- ISCED 6: Bachelor's or equivalent level. ISCED 6 programs are traditionally offered by universities and equivalent tertiary educational institutions (Eurydice, 2017, p. 146). In most cases the entry age is 18 or 19.

Strictly speaking, tertiary education comprises ISCED levels 5, 6, 7 and 8 (ISCED 2011, 2012, p. 46), but for the positioning of Chinese as a foreign language in Slovenia, the detailed classification is not relevant.

\section{Starting ages for learning foreign languages as compulsory subjects}

According to the Eurydice Report (2017), in most countries, the starting age of the first foreign language as a compulsory subject ranges from 6 to 8 , which equals the first year(s) of primary education. As shown in Figure 1 below, Slovene children start to learn the first foreign language as a compulsory subject at the age of 7 , i.e. in the second grade of primary education (ISCED 1 ). ${ }^{3}$

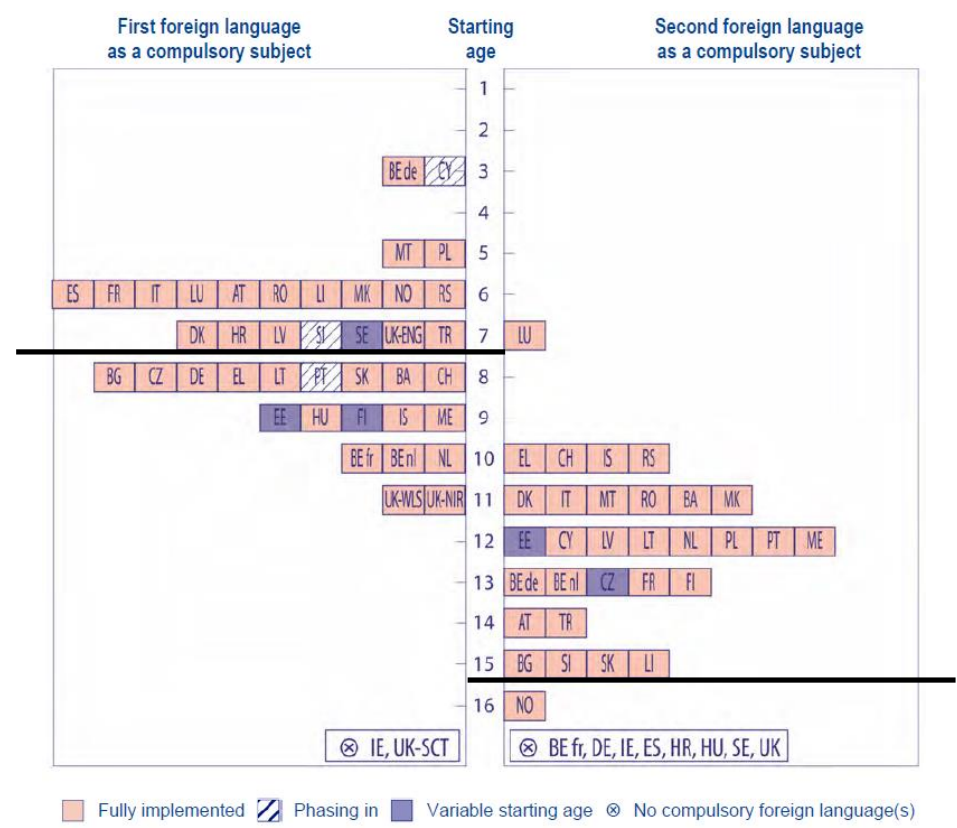

Figure 1: Starting ages at which learners meet with the first and second foreign language as compulsory subjects in different EU coutries, 2015/16. (Source: Eurydice, 2017, p. 30)

\footnotetext{
${ }^{3}$ The data in Figure 1 refer to 2015/16, when Slovenia was in the phasing-in period. Since 2016/17, the changes have been fully implemented.
} 
Compared to the previous decades, the starting age of first foreign language as a compulsory subject is slowly lowering, i.e. from age 11 in 1983/84 down to age 7 in 2017/18 (see Table 1).

Table 1: Starting age of first foreign language as a compulsory subject in primary education in Slovenia, 1983/1984-2017/2018.

\begin{tabular}{lcl}
\hline Reference years & Age & Source \\
\hline $1983 / 1984$ & 11 & Figure B3 (Eurydice, 2008, p. 35) \\
$1993 / 1994$ & 11 & Figure B2 (Eurydice, 2012, p. 28) \\
$2002 / 2003$ & 9 & Figure B2 (Eurydice, 2017, p. 32) \\
$2006 / 2007$ & 9 & Figure B2 (Eurydice, 2012, p. 28) \\
$2010 / 2011$ & 9 & Figure B2 (Eurydice, 2017, p. 32) \\
$2015 / 2016$ & $7^{*}$ & Figure B2 (Eurydice, 2017, p. 32) \\
$2016 / 2017+$ & 7 & (Eurydice, 2017, p. 157)
\end{tabular}

* Phasing in

The second foreign language as a compulsory subject is introduced at the age 15, i.e. when students enter upper secondary education (ISCED 3). There were attempts to lower the age at which learning the second foreign language would become compulsory for all students in Slovenia. In 2011, Slovenia was in the phasing-in period to lower the age from 15 to 12, but the reform was not implemented and the second foreign language has not entered into the lower secondary education (ISCED 2) yet.

Although the second foreign language is not compulsory at the lower secondary education, the figures show that students tend to grab the opportunity to learn a second foreign language in the scope of compulsory elective courses ${ }^{4}$ (obvezni izbirni predmet). ${ }^{5}$

While there were only $24.9 \%$ students that learnt two or more foreign languages in 2005, this proportion increased to $56.3 \%$ in 2014 (see Figure 2 below). According to informal data, in the recent years this proportion is increasing. However, official data from 2014 show that Slovenia ranks 23rd at EU level.

Figure 2 also shows that the proportion of students that learnt just one foreign language decreased from $73.3 \%$ in 2005 to $43.7 \%$ in 2014 . Moreover, the group of students who did not learn any foreign language in 2014 (1.8\%) died out untill 2014.

\footnotetext{
${ }^{4}$ Eurydice (2017) uses the term "core curriculum option".

${ }^{5}$ For the full list of available courses see Abecedni seznam izbirnih predmetov $v$ osnovni šoli.
} 


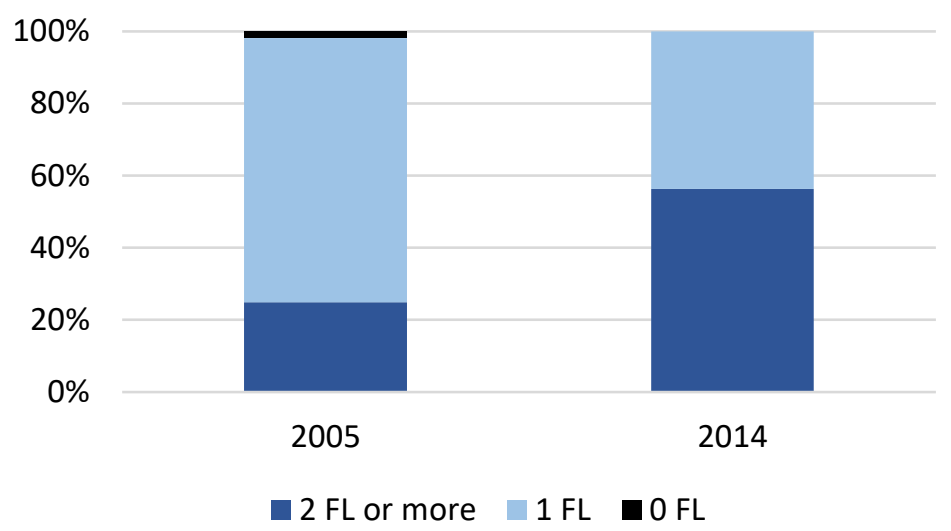

Figure 2: Trends in the proportion of students learning foreign languages at ISCED 2 in Slovenia, by number of languages, in 2005 and 2014. (Source of data: Eurydice, 2014, p. 166)

\section{Available foreign languages at lower secondary education}

After the fully implemented reform in $2016 / 17$, all students start learning a foreign language as a compulsory subject from the age 7. Slovenia is one of those countries where schools choose languages from a set list. As stated in the Eurydice, "some education authorities specify the 'preferred' foreign languages to be offered as first or second foreign languages, but do not make them mandatory" (2017, p. 43).

Languages that schools in Slovenia offer include English, German, French, Spanish, Russian, Italian, Hungarian, Latin, Croatian, Serbian, Macedonian and Chinese. (Abecedni seznam izbirnih predmetov $v$ osnovni šoli; Eurydice, 2017, p. 47)

The mostly learnt foreign language at ISCED 2 level in Slovenia is English with 99.7\% of all students, followed by German (47.8\%), French (2.9\%) and Spanish (2.1\%) (Eurydice, 2017, pp. 169-170). This means that in approximately $99.7 \%$ cases students learn English as their first foreign language, and in approximately $0.3 \%$ cases their first foreign language is German. However, since $56.3 \%$ of all students learn two foreign languages or more (see Figure 2 above), the total amount of students learning German reaches $47.5 \%$ of the entire ISCED 2 population, etc. The same principle applies to the presented data at ISCED 3 level in Chapter 4 below.

Schools are free to opt for other languages from the above mentioned list according to their respective capabilities and students' interests. 


\section{Available foreign languages at upper secondary education}

The upper secondary education (ISCED 3) in Slovenia encompasses general education (splošno izobraževanje) on one side, and vocational education (srednje strokovno izobraževanje) and technical education (tehniško izobraževanje) on the other side.

General education is further divided into different types of four-year gimnazija programs (gimnazija, classical gimnazija, technical gimnazija, gimnazija of economics, gimnazija of arts).

Vocational and technical education is divided into educational programs of different difficulty levels, such as short upper secondary vocational ( 2 years) and upper secondary vocational education programs ( 3 years), in which students shall pass the school-leaving exam to successfully complete the program; upper secondary technical education programs (4 years), vocational technical education programs ( 2 additional years after completing a vocational program) and the vocational course (1 year), in all of which students shall pass the vocational matura to successfully complete the education program. (Taštanoska, 2015, p. 29)

All general education students must study two foreign languages until they reach 19. Some educational pathways have three languages as compulsory subjects. When they finish school, all VET students will have learnt one foreign language as a compulsory subject for 12 years. (Eurydice, 2017, p. 157)

General education programs (i.e. gimnazija programs) in Slovenia offer languages that include English, German, French, Spanish, Russian, Italian, Latin, Greek (Classical), and Chinese. (Učni načrti za gimnazije; Eurydice, 2017, p. 47)

The most learnt foreign language at ISCED 3 level in Slovenia is English with 98.2\% of all students of general education, followed by German (63.4\%), Spanish (13.0\%), and French (10.8\%) (Eurydice, 2017, pp. 169-170). Schools are free to opt for other languages from the above mentioned list, according to their respective capabilities and students' interests.

\section{Chinese as a foreign language}

\subsection{Chinese in EU countries}

In Europe, some education systems lay down their own requirements about what languages schools are obliged to offer, but the majority of European countries should follow a common list of foreign languages from which schools choose (Eurydice, 2017, p. 45).

Chinese as a foreign language must be provided in Malta, at both lower and upper secondary level, for example. Students can also take national tests of Chinese. In nine 
other EU countries, however, schools may choose Chinese to offer as a foreign language, as shown in Table 2.

Through the prism of East Asian languages and compared to Chinese, Japanese may be offered in five European countries at lower and/or upper secondary level, as shown in Table 3 and further discussed by Moritoki Škof (2018).

Table 2: Inclusion of Chinese in the curriculum, ISCED 1 to 3, 2015/16

(Source of data: Eurydice, 2017, p. 47).

\begin{tabular}{lccc}
\hline EU country & ISCED 1 & ISCED 2 & $\begin{array}{c}\text { ISCED 3 } \\
\text { general }\end{array}$ \\
\hline Malta & & $\bullet$ & $\bullet$ \\
Belgium - fr. & & & $\bullet$ \\
Denmark & & & $\bullet$ \\
France & $\bullet$ & $\bullet$ & $\bullet$ \\
Italy & & & $\bullet$ \\
Hungary & $\bullet$ & $\bullet$ & \\
Netherlands & & $\bullet$ & $\bullet$ \\
Portugal & & & $\bullet$ \\
Slovenia & & $\bullet$ & $\bullet$ \\
Turkey & & $\bullet$ & $\bullet$ \\
\hline
\end{tabular}

Table 3: Inclusion of Japanese in the curriculum, ISCED 1 to 3, 2015/16

(Source of data: Eurydice, 2017, p. 47).

\begin{tabular}{|c|c|c|c|}
\hline EU country & ISCED 1 & ISCED 2 & $\begin{array}{l}\text { ISCED } 3 \\
\text { general }\end{array}$ \\
\hline Denmark & & & $\bullet$ \\
\hline France & & $\bullet$ & $\bullet$ \\
\hline Italy & & & $\bullet$ \\
\hline Romania & & $\bullet$ & $\bullet$ \\
\hline Turkey & & $\bullet$ & $\bullet$ \\
\hline
\end{tabular}

\subsection{Chinese in Slovenia}

At lower secondary education in Slovenia, Chinese is one of the 12 languages, available as a second foreign language, along with English, German, French, Spanish, Russian, Italian, Hungarian, Latin, Croatian, Serbian, and Macedonian. It was first launched in 2013/14. Straus (2018, p. 16, Table 1) presents yearly data on which schools offer Chinese as a compulsory elective course, and how many students were enrolled in the 
last five years. Probably due to the low figures, ${ }^{6}$ these data do not reveal how many students had learnt Chinese for one, two or three years. According to the regulations, the selected language is taught two hours per week, for one to three years, in total 70 to 204 hours.

In the same year, 2013/14, Chinese was introduced at upper secondary education. As stated in Chapter 4, second foreign language is mandatory for students on the gimnazija programs. Schools are obliged to select one of the following eight languages as second foreign language: English, German, French, Italian, Spanish, Russian, Latin and Greek. Chinese is not available as second foreign language yet, but it can be selected as third foreign language. Recently, new initiatives have emerged to endorse Chinese as the 9 th second foreign language.

Therefore, a curriculum renewal is needed, not only to define the scope and standards of Chinese as second foreign language, but also to reconsider the horizontal and vertical structure of available modules.

\section{Curriculum renewal}

Within the gimnazija programs, foreign languages are divided into seven modules, based on the total number of teaching hours and students' prior knowledge. This does not mean that all the modules should be carried out, but rather that they may be offered to the students according to school's respective capabilities and students' interests.

"Module I" sets the framework for a first foreign language (FL1); "Module II" for a second foreign language (FL2) with prior knowledge obtained in lower secondary education; "Module III" represents FL2 without any prior knowledge; whereas Modules IV-VII define guidelines for a third/fourth foreign language (FL3/FL4). Table 4 shows the seven modules with their corresponding teaching hours and required levels of proficiency.

Table 4: Language modules at gimnazija programs (ISCED 3), by teaching hours

\begin{tabular}{|c|c|c|c|c|c|c|c|}
\hline & $\begin{array}{c}\text { Mod. I } \\
\text { FL1 }\end{array}$ & $\begin{array}{c}\text { Mod. II } \\
\text { FL2 } \\
\text { follow-on }\end{array}$ & $\begin{array}{l}\text { Mod. III } \\
\text { FL2 } \\
\text { beginner }\end{array}$ & $\begin{array}{l}\text { Mod. IV } \\
\text { FL3 } \\
\text { beginner }\end{array}$ & $\begin{array}{l}\text { Mod. V } \\
\text { FL3/FL4 } \\
\text { beginner }\end{array}$ & $\begin{array}{l}\text { Mod. VI } \\
\text { FL3/FL4 } \\
\text { beginner }\end{array}$ & $\begin{array}{l}\text { Mod. VII } \\
\text { FL3/FL4 } \\
\text { beginner }\end{array}$ \\
\hline & 420 & 420 & $350-420$ & $280-315$ & 210 & 140 & 70 \\
\hline \multicolumn{8}{|l|}{ Proficiency } \\
\hline - at the start & $\mathrm{A} 2+$ & $\mathrm{A} 1+$ & - & - & - & - & - \\
\hline - at the end & B2 & $\mathrm{B} 1+$ & B1 & $A 2+$ & $\mathrm{A} 2$ & A1+ & $\mathrm{A} 1$ \\
\hline
\end{tabular}

\footnotetext{
${ }^{6}$ Students who choose Chinese as an extracurricular activity are not included in the report.
} 
All the existing language curricula are based on the Common European Framework of Reference for Languages (CEFR). As pointed out in CEFR, this document 'provides a common basis for the elaboration of language syllabuses, curriculum guidelines, examinations, textbooks, etc. across Europe' (2001, p. 1). The framework itself is open and flexible, and so are the eight endorsed language curricula.

For the languages with several effective, well-thought-out textbooks and teaching materials that were designed in line with CEFR and recommended by Ministry of Education, the looseness of curricula does not significantly affect the teaching process among schools and teachers. This fact does not question the value and importance of teachers' contributions in the pedagogical process. However, great extent of flexibility is not advisable in case of Chinese.

Foreign students-oriented Chinese textbooks are flourishing, promoting various approaches to language and culture teaching/learning. Some of them are related to Chinese standards and language proficiency levels, some of them promote interaction and communication, some other aspects. Even if there were a consensus about which textbook(s) are comparable and should be promoted as the core materials, there would be a gap between students' gained knowledge on one side, and the expected proficiency levels and CEFR scales on the other side. Even language learners themselves would quickly notice the discrepancy between their proficiency in Chinese compared to European languages.

The Common European Framework of Reference provides detailed descriptions of skills by level, but because it is written in a language-neutral format, it is not directly useful for the final users, i.e. language teachers. Therefore, the new curriculum for Chinese as foreign language in Slovenia strongly promotes the application of European Benchmark Framework for Chinese (EBCL), which is based upon CEFR, and aimed at Europeans learning the Chinese language (http://ebcl.eu.com/).

In light of available contact hours and expected proficiency levels for the eight existing languages, we propose the following proficiency levels for Chinese (see Table 5).

Table 5: Proposed proficiency levels for European languages vs. Chinese, ISCED 3

\begin{tabular}{|c|c|c|c|c|c|c|c|}
\hline & $\begin{array}{c}\text { Mod. I } \\
\text { FL1 }\end{array}$ & $\begin{array}{l}\text { Mod. II } \\
\text { FL2 } \\
\text { follow- } \\
\text { on }\end{array}$ & $\begin{array}{l}\text { Mod. III } \\
\text { FL2 } \\
\text { beginner }\end{array}$ & $\begin{array}{l}\text { Mod. IV } \\
\text { FL3 } \\
\text { beginner }\end{array}$ & $\begin{array}{l}\text { Mod. V } \\
\text { FL3/FL4 } \\
\text { beginner }\end{array}$ & $\begin{array}{l}\text { Mod. VI } \\
\text { FL3/FL4 } \\
\text { beginner }\end{array}$ & $\begin{array}{l}\text { Mod. VII } \\
\text { FL3/FL4 } \\
\text { beginner }\end{array}$ \\
\hline & 420 & 420 & $350-420$ & $280-315$ & 210 & 140 & 70 \\
\hline \multicolumn{8}{|l|}{ Proficiency } \\
\hline - EU languages & B2 & B1+ & B1 & $\mathrm{A} 2+$ & $\mathrm{A} 2$ & $A 1+$ & $\mathrm{A} 1$ \\
\hline - Chinese & & & $A 2+$ & $\mathrm{A} 2$ & $\mathrm{~A} 1+$ & $\mathrm{A} 1$ & A1.1 \\
\hline
\end{tabular}


The proposed levels are a realistic and achievable goal. In combination with $\mathrm{EBCL}$ guidelines, it would be perfectly transparent which contents an individual module includes.

\section{Conclusions}

This paper presents a proposal of curriculum renewal for Chinese as a foreign language at the upper secondary education. The introduction of five modules would be beneficial not only for the students of the same level (ISCED 3), but also for the vertical continuity from ISCED 2 to ISCED 3 on one hand, and from ISCED 3 to ISCED 6 on the other. The transition ISCED 3 to ISCED 6 represents the students who decide to enroll in Chinese studies at university level after finishing one of the gimnazija programs.

According to the Ministry's official data on the number of learners of Chinese in the recent years, the vertical alignment does not seem to be necessary yet, but it will be a valuable reform in the long run, since it sets up precise standards in Chinese language acquisition.

Furthermore, we believe that the collected data should not be an obstacle for the approval of Chinese as a second foreign language (Module III). Nevertheless, a language curriculum does not mean that all the modules must be carried out, but that they can be offered to the students according to the school's respective capabilities and students' interests.

\section{Acknowledgement}

The work presented in this article has been supported by the ARRS research programme P6-00243 "Asian languages and cultures".

\section{References}

Abecedni seznam izbirnih predmetov v osnovni šoli, (n.d.). Retrieved from http://www.mizs.gov.si/si/delovna podrocja/direktorat za predsolsko vzgojo in osnovno solstvo/osnovno solstvo/program/abecedni seznam izbirnih predmetov $v$ osnovni soli/

Can-do Statements at Levels A1-A2+. (2012). The European Benchmarking Chinese Language (EBCL) Project Team. Brussels. Retrieved from http://ebcl.eu.com/wp-content/uploads/2013/02/EBCL-A1-A2+-Can-do-Statements-Oct2012.pdf

Common European Framework of Reference for Languages: Learning, teaching, assessment Structured overview of all CEFR scales. (n.d.). Retrieved from https://rm.coe.int/168045b15e 
Council of Europe (2001). Common European Framework of Reference for Languages: Learning, teaching, assessment. Cambridge: Cambridge University Press. Retrieved from https://www.coe.int/t/dg4/linguistic/source/framework en.pdf

European Commission/EACEA/Eurydice, (2008). Key Data on Teaching Languages at School in Europe - 2012 Edition. Eurydice Report. Retrieved from http://eacea.ec.europa.eu/about/eurydice/documents/KDL2008 EN.pdf

European Commission/EACEA/Eurydice, (2012). Key Data on Teaching Languages at School in Europe - 2012 Edition. Eurydice Report. Retrieved from http://eacea.ec.europa.eu/education/Eurydice/documents/key data series/143EN.pdf

European Commission/EACEA/Eurydice, (2017). Key Data on Teaching Languages at School in Europe - 2017 Edition. Eurydice Report. Luxembourg: Publications Office of the European Union. Retrieved from https://webgate.ec.europa.eu/fpfis/mwikis/eurydice/images/0/06/KDL 2017 internet.pdf. International Standard Classification of Education. ISCED 2011, (2012). UNESCO Institute for Statistics. Canada. Retrieved from http://uis.unesco.org/sites/default/files/documents/international-standardclassification-of-education-isced-2011-en.pdf

Moritoki Škof, N. (2018). Learner Motivation and Teaching Aims of Japanese Language Instruction in Slovenia. Acta Linguistica Asiatica, 8(1), 39-50. doi:10.4312/ala.8.1.39-50

Straus, B. (2018). Poučevanje tujih jezikov v slovenskem šolskem sistemu. Prostor tudi za japonščino? Acta Linguistica Asiatica, 8(1), 9-25. doi:10.4312/ala.8.1.9-25

Supporting Documents to Can-do Statements. (2012) The European Benchmarking Chinese Language (EBCL) Project Team. Brussels. Retrieved from http://ebcl.eu.com/wp-content/uploads/2013/02/EBCL-Supporting-Documents-for-CDSOct-2012.pdf

Taštanoska, T. (Ed.). (2015). The EDUCATION SYSTEM in the Republic of Slovenia. Ljubljana: Tiskarna Radovljica. Retrieved from http://203.gvs.arnes.si/BROSURA-vzgoja-in-izobrazevanje-v-RS-ENG/files/assets/common/ downloads/publication.pdf

Učni načrti za gimnazije, (n.d.). Retrieved from http://eportal.mss.edus.si/msswww/programi2015/programi/gimnazija/ucni nacrti.htm 